\title{
Khazanah
}

\section{SRI SOEMANTRI}

\begin{abstract}
“...apabila suara saya ini ibarat teriakan di padang pasir yang sangat luas - yang mungkin tidak ada yang memperhatikan - akan terus saya saya kumandangkan. Hanya itulah yang dapat saya sumbangkan kepada negara dan bangsa sebagai seorang guru di bidang Hukum Tata Negara di Perguruan Tinggi."
\end{abstract}

(21 Februari 1987)

\begin{abstract}
"Semoga energi yang berserakkan dalam hati kami masing-masing yang tergambar dalam perdebatan dan hasil kajian kami ini dapat dirajut melalui proses politik formal yang berlangsung di balik koridor hukum positif yang menjadi pedoman untuk kebaikan dan kemaslahatan Indonesia ke masa depan."
\end{abstract}

(6 Mei 2004)

Dua cuplikan di atas menggambarkan sosok utuh Prof. (em). Dr. Sri Soemantri Martosoewignjo dalam dunia Hukum Tata Negara (HTN) Indonesia. Cuplikan pertama diucapkannya sebagai bagian penutup dalam Pidato Ilmiah yang menandai penerimaan jabatan Guru Besar dalam bidang HTN tahun 1987. Saat itu, ia menyampaikan pidato yang berjudul "Undang-Undang Dasar dan Ketetapan Majelis Permusyawaratan Rakyat Sebagai Produk Majelis Permusyawaratan Rakyat". Tujuh belas tahun berselang, di hadapan Sidang Paripurna Badan Pekerja Majelis Permusyawaratan Rakyat (MPR) dalam kapasitasnya sebagai Ketua Komisi Konstitusi, Sri Soemantri kembali menyampaikan harapan yang dituangkan dalam cuplikan kedua. Idealisme sebagai seorang guru tampak nyata dalam kedua cuplikan tersebut. la sadar bahwa HTN merupakan cabang ilmu hukum yang 'dijauhi' oleh banyak orang karena sangat bersentuhan dengan kekuasaan dan karenanya besar kemungkinan pendapat-pendapat ilmiah akan diredam karena berbahaya bagi penguasa. Saat Reformasi meniscayakan terjadinya perubahan Undang-Undang Dasar 1945 (UUD 1945)-dengan segala kelebihan dan kekurangan-Sri Soemantri kembali menyuarakan harapan seorang guru besar kepada para wakil rakyat agar bersedia berjalan di ranah hukum positif untuk menelisik ulang berbagai kekurangan yang ada dalam UUD 1945 Perubahan dan menggunakan hasil kerja Komisi yang dipimpinnya untuk menata ulang sistem ketatanegaraan Indonesia demi kemaslahatan yang lebih luas.

Dalam perjalanannya, Sri Soemantri dikenal sebagai seseorang dengan latar belakang beragam mulai dari pejuang kemerdekaan, aktivis pergerakan, politisi, hingga ilmuwan HTN. Meskipun demikian, peran sebagai ilmuwan merupakan peran yang sangat dibanggakannya. Diyakininya menjadi guru merupakan ladang amalan yang tak akan pernah terputus, yang membawa kedamaian dalam hidup,

PADJADJARAN Jurnal IImu Hukum Volume 3 Nomor 1 Tahun 2016 [ISSN 2460-1543] [e-ISSN 2442-9325] 
terutama saat menyaksikan para muridnya melesat berprestasi dan menyumbangkan beragam kontribusi bagi negeri yang sangat dicintainya: Indonesia.

\section{A. Sketsa Biografi'}

Dilahirkan di Tulung Agung 15 April 1926, Sri Soemantri Martosoewignjo anak dari pasangan Isbandi Martosoewignjo-Artini, dikenal luas sebagai pakar HTN, khususnya Hukum Konstitusi. Bidang ini menjadi identik dengan dirinya setelah ia berhasil mempertahankan disertasi dengan judul "Prosedur dan Mekanisme Perubahan UUD 1945" pada tahun 1978. Keinginannya untuk mencapai tingkat pendidikan tertinggi sangat dipengaruhi oleh keyakinan kuat sang Ibu bahwa kelak putranya yang keenam akan mampu menjadi orang besar. Dibesarkan dalam situasi serba sulit pada masa Revolusi Kemerdekaan, membawa Sri Soemantri tumbuh menjadi seorang manusia dengan nasionalisme tinggi melalui berbagai bacaan mengenai pemikiran-pemikiran serta menghadiri pidato-pidato para guru bangsa, antara lain Ki Hadjar Dewantoro, Bung Karno, Bung Hatta dan Ki Mas Mansjur. Arti penting pendidikan untuk memerdekaan suatu bangsa diperolehnya dari pikiran Ki Hadjar Dewantoro. Kecintaannya akan tanah air diwujudkan pula saat ia bergabung dengan Tentara Pelajar (TRIP) yang kemudian dilanjutkan dengan aktivitasnya di berbagai organisasi mahasiswa, misalnya Gerakan Mahasiswa Marhaenis yang menjadi cikal bakal Gerakan Mahasiswa Nasionalis Indonesia. Selain itu, Sri Soemantri juga masuk dalam lingkaran Partai Nasional Indonesia (PNI) yang mengantarnya menjadi anggota termuda Konstituante dalam usia 29 tahun. Baginya Konstituante bukan semata-mata badan pembentuk konstitusi, melainkan sebuah 'perguruan tinggi' yang menyediakan ruang membuat interpretasi terhadap berbagai perdebatan hukum dan politik mengenai independensi Konstituante, proses pengisian pimpinan Konstituante, serta hal-hal prinsipil lainnya berkenaan dengan konstitusi, termasuk materi muatan. Meskipun berbagai perdebatan acapkali diakhiri dengan pemungutan suara, Sri Soemantri mencatat salah satu pelajaran penting, "politik yang sering dijuluki the art of possibility adalah sejatinya menuntut saling menerima perbedaan dan mengelolanya dalam sebuah kompromi demi kepentingan rakyat banyak". ${ }^{2}$

Ditunjuk memimpin Sub-Komisi HAM dalam pembahasan internal di Konstituante, memberikan kesempatan kepada Sri Soemantri memahami HAM lebih mendasar, yang kelak akan sangat bermanfaat saat ia diminta sebagai anggota Komisi Nasional HAM tahun 1990-an. Salah satu perdebatan sengit yang terjadi

1 Lihat Hikmat Kusumaningrat dan Purnama Kusumaningrat, Mengawal Konstitusi: Pengabdian Seorang Guru Besar, Bandung: Unpad Press, 2006.

2 Ibid., hlm. 63. 
dalam Sub-Komisi berkenaan dengan acuan gagasan HAM, dalam arti mencari argumentasi perlunya HAM diatur dalam konstitusi. Ada yang mendasarkan pada Al-Quran dan Hadis, paham liberal, paham sosialis, ataupun pengalaman bangsa Indonesia dalam perjuangan kemerdekaan. Perbedaan pandangan ini berakibat pada perbedaan "penafsiran, perumusan pengertian-pengertian dan sejauhmana hak-hak diatur serta siapa saja yang bisa dilindungi oleh hak-hak tersebut". ${ }^{3}$ Salah satu hak yang diperdebatkan adalah hak milik. Fraksi-fraksi partai Islam berpendirian bahwa hak milik adalah karunia Allah dan oleh karenanya penggunaan hak tersebut harus memberikan manfaat bagi orang lain. Dengan kata lain, hak milik mempunyai fungsi sosial. Perdebatan mengenai hak milik ini muncul saat para juru bicara fraksi meminta perhatian mengenai pentingnya memahami HAM dalam konteks Indonesia saat merumuskan hak-hak asasi dalam UUD. ${ }^{4}$ Dalam kesempatan memimpin tersebut, Sri Soemantri mengusulkan adanya hak suaka politik bagi warga negara asing dari pengejaran karena keyakinannya. ${ }^{5}$ Akhirnya, setelah melalui perdebatan panjang dan pemungutan suara, terdapat 22 hak asasi yang sudah disetujui untuk dirumuskan dalam pasal-pasal UUD. ${ }^{6}$

Kembali ke kampus menjadi keputusan Sri Soemantri saat Dekrit Presiden 5 Juli 1959 mengakhiri kiprahnya di Konstituante. Dekrit ini menyatakan pembubaran Konstituante dan memberlakukan kembali UUD 1945. Sesungguhnya PNI telah mempersiapkan tugas berikut baginya yakni diperbantukan di sebuah komisi yang akan dipimpin oleh Sri Sultan Hamengkubuwono IX di Jakarta, namun tugas tersebut ditolaknya. ${ }^{7}$ Keinginannya untuk segera menyelesaikan kuliah di Universitas Padjadjaran mengalahkan berbagai tawaran politik. Adalah Mr. Ernst Utrecht yang menjadikannya sebagai calon asisten dosen. Tahun 1964 ia berhasil merampungkan kuliahnya dengan bidang kajian HTN. Pemilihan ini bukan sematamata karena pengalamannya menjadi anggota Konstituante, melainkan lebih didasarkan pada pencapaian nilai-nilai mata kuliah yang terbilang baik di bidang ilmu kenegaraan. Saat mengetahui Sri Soemantri memilih spesialisasi HTN, Usep Ranawidjaja segera menawarkan menjadi asistennya pada mata kuliah HTN dan Perbandingan HTN.

Sekitar tahun 1964-an Sri Soemantri diminta menjadi Pembantu Dekan III bidang Kemahasiswaan. Di tengah situasi politik yang memanas, tugas yang diembannya tidak ringan karena banyak mahasiswa yang harus 'diselamatkan' studinya akibat adanya tuduhan-tuduhan politik tertentu. Namun, tahun 1966 Sri

\footnotetext{
3 Ibid., hlm. 81.

4 Ibid., hlm. 82.

5 Ibid., hlm. 80.

6 Ibid., hlm. 83.

7 Ibid., hlm. 125.
} 
Soemantri melepaskan jabatannya karena adanya "penggunaan kekuatan massa dalam penyelesaian masalah kemahasiswaan". ${ }^{8}$

Keputusan mundur sebagai Pembantu Dekan menyebabkan ia memiliki banyak waktu untuk mencurahkan pikiran, melakukan penelitian, serta menulis buku. Pada masa itu, ia menuangkan pikirannya mengenai sistem dua partai yang terinspirasi dari gagasan yang dilontarkan oleh Pangdam VI Siliwangi saat itu, Mayjen H.R. Dharsono. Hasilnya, lahir sebuah buku sebagai respon seorang ilmuwan HTN terhadap rencana penyelenggaraan pemilihan umum sesuai dengan Ketetapan MPRS serta 'alotnya' pembahasan RUU paket politik, yang terdiri dari RUU Kepartaian, Keormasan dan Kekaryaan; RUU tentang Pemilihan Umum; serta RUU tentang Susunan dan Kedudukan MPR, DPR dan DPRD. Di kemudian hari buah pikiran Sri Soemantri ini dipandang sebagai 'terobosan' oleh komunitas HTN yang mendekatkan kajian IImu Politik dengan IImu HTN. Mengenai hal ini Sri Soemantri berpendapat:

"Saya menyadari bahwa masalah sistem dua partai adalah masalah politik. Sebagai sistem politik, ia menjadi domein ilmu politik. Namun ketika ia hendak dilaksanakan, tentunya perlu bentuk hukum yang mewadahinya sesuai hirarki perundang-undangan yang berlaku. Inilah alasan utama saya tertarik untuk melakukan penelitian tentang sistem dua partai ini." 9

Tahun 1976, Sri Soemantri memulai program S3 di bawah bimbingan Prof. Dr. Rochmat Soemitro sebagai Ketua Tim Promotor dan Prof. Mr. Crince Le Roy-Guru Besar HTN pada Rijksuniversiteit di Utrecht Belanda-sebagai Co-Promotor. Atas beasiswa Pemerintah Belanda, Sri Soemantri berkesempatan melakukan sandwich program selama kurang lebih 1 tahun di Belanda. Pada 22 Juli 1978 di hadapan Sidang Terbuka Senat Guru Besar Universitas Padjadjaran (Unpad), ia berhasil mempertahankan disertasinya. Dilihat dari durasi waktu, Sri Soemantri menyelesaikan studinya dalam waktu yang cukup singkat yang disebutnya sebagai hasil bimbingan Prof. Rochmat serta ketelitian Prof. Crince Le Roy untuk menyusun argumentasi-argumentasi ilmiah sebagai faktor utama. ${ }^{10}$

Pencapaian gelar akademik tertinggi membuat Sri Soemantri makin disibukkan oleh berbagai kegiatan di kampus dan di luar kampus, termasuk terlibat dalam berbagai forum yang diselenggarakan oleh Dewan Pertahanan Keamanan Nasional (Wanhankamnas) untuk menyusun rancangan Garis-Garis Besar Haluan Negara (GBHN). Di kampusnya, Sri Soemantri diangkat menjadi Pembantu Dekan I Bidang Akademik, yang dilanjutkan dengan pengangkatannya sebagai Dekan selama 2 (dua) periode. Pada masa ini, Sri Soemantri dikenal sebagai Dekan yang

8 Ibid., hlm. 134.

9 Ibid., hlm. 36-137.

10 Ibid., hlm. 144. 
memperlihatkan dua karakter sekaligus, yakni sebagai seorang scholar dan seorang 'manager', dengan tugas utama mengembangkan sistem manajemen pendidikan hukum. Sebagai seorang scholar atau ilmuwan, Sri Soemantri mampu mengembangkan pemikiran-pemikiran HTN yang melambungkan nama Unpad di tingkat nasional dan internasional. Sedangkan sebagai 'manager', ia sangat mengedepankan pengembangan sumber daya manusia, khususnya dosen-dosen. Di bawah kepemimpinannya, para dosen 'diwajibkan' mengikuti jenjang pendidikan lanjutan baik di Unpad maupun di luar Unpad. Setelah menyelesaikan masa jabatan sebagai Dekan, Sri Soemantri diminta menjadi Rektor Universitas 17 Agustus di Jakarta selama kurang lebih delapan tahun. Pada tahun 2000, ia diangkat menjadi Rektor Universitas Jayabaya. Seakan tidak ingin melepas Sri Soemantri, Yayasan yang menaungi Universitas Jayabaya tetap memintanya sebagai 'penasihat' setelah masa jabatan sebagai Rektor berakhir.

Di luar dunia kampus, Sri Soemantri terlibat dalam dua lembaga penting, yaitu Komisi Nasional Hak Asasi Manusia (Komnas HAM) tahun 1993, serta Komisi Konstitusi tahun 2003. Keterlibatannya di Komnas HAM di samping pengalamannya sebagai anggota Konstituante, antara lain ditopang oleh berbagai keikutsertaan Sri Soemantri dalam kelompok kerja Wanhankamnas yang memungkinkannya mengumpulkan, mempelajari, dan mendiskusikan berbagai hal mengenai HAM di Indonesia. Bahkan Sekjen Wanhankamnas yang saat itu dijabat oleh Laksamana Madya Machmud Subarkah memintanya mempersiapkan Rancangan Ketetapan MPR mengenai HAM. ${ }^{11}$ Saat menjadi anggota Komnas HAM, Sri Soemantri ditunjuk sebagai Ketua Sub Komisi Pengkajian Instrumen Hak Asasi Manusia. Di bawah kepemimpinannya, Sub Komisi ini menghasilkan beberapa rekomendasi, antara lain: ${ }^{12}$ Pertama; perlunya Indonesia segera meratifikasi beberapa kovenan, yaitu Kovenan Menentang Penyiksaan dan Perlakuan atau Penghukuman Yang Kejam, Tidak Manusiawi atau Merendahkan Martabat Manusia; Kovenan Penghapusan Segala Bentuk Diskriminasi Rasial; Kovenan Hak-hak Sipil dan Politik; serta Kovenan Hak-hak Ekonomi, Sosial dan Budaya. Hasil kajian ini diserahkan kepada Pemerintah agar dapat ditindaklanjuti. Kedua; pengkajian Undang-Undang Nomor 11 Pnps 1963 tentang Pemberantasan Tindak Pidana Subversi (UU Anti Subversi). Menurut hasil kajian Sub Komisi ini, UU Anti Subversi mengandung berbagai kelemahan substansial yang berpotensi melanggar HAM. Pada tanggal 9 Februari 1996, Komnas HAM secara resmi mengirim surat kepada Presiden Soeharto agar mencabut UU tersebut.

Reformasi yang memunculkan keniscayaan melakukan perubahan UUD 1945 membawa Sri Soemantri kembali ke arena nasional. Ikut serta sebagai Tim Ahli PAH I MPR, ia menyaksikan perdebatan-perdebatan dalam Badan Pekerja MPR, yang

11 Ibid., hlm. 166.

12 Ibid., hlm. 170-171. 
seakan-akan memutar kembali kenangan saat terlibat sebagai anggota Konstituante. Sayangnya, rangkaian perubahan UUD 1945 yang berakhir pada tahun 2002 memunculkan berbagai kritik tajam terhadap hasil perubahan dimaksud. Tidak terkecuali Sri Soemantri. Baginya amandemen dilakukan sangat tergesa-gesa, meminimalkan partisipasi publik yang lebih luas. Sebagai upaya meredam kritikan-kritikan tersebut, MPR membentuk Komisi Konstitusi melalui Ketetapan MPR No. II/MPR/2002 yang diikuti dengan Keputusan MPR No. 4/MPR/2003 tentang Susunan, Kedudukan, Kewenangan dan Keanggotaan Komisi Konstitusi.

Memenuhi 'panggilan sejarah', pada tanggal 8 Oktober 2003 Sri Soemantri terpilih menjadi Ketua Komisi Konstitusi. Tantangan terbesar Komisi ini adalah menghasilkan sebuah kajian komprehensif terhadap UUD 1945 Perubahan. Akhirnya disepakati dibentuk dua Sub-Komisi yang menghasilkan dua naskah: pertama, Kajian Akademik tentang Perubahan UUD RI Tahun 1945, dan kedua, Naskah Perubahan UUD RI Tahun 1945. Tanggal 6 Mei 2004 secara resmi Sri Soemantri menyerahkan hasil kerja Komisi yang dipimpinnya dalam Rapat Paripurna Badan Pekerja MPR yang dihadiri oleh Amien Rais, Ketua MPR saat itu.

\section{B. Konstitusi}

Adalah pengalamannya menjadi anggota Konstituante yang menjadi faktor utama Sri Soemantri mencurahkan perhatiannya pada konstitusi, khususnya UUD 1945. Berbagai perdebatan yang muncul saat sidang-sidang Konstituante menyadarkannya akan arti penting konstitusi bagi suatu negara.

Dalam kajian Teori dan Hukum Konstitusi terdapat beberapa bahasan fundamental. K.C. Wheare, misalnya, dalam bukunya menjelaskan hal-hal yang berkenaan dengan pengertian, klasifikasi, materi muatan, otoritas, serta perubahan konstitusi. $^{13}$ Tentang makna konstitusi, Sri Soemantri menyebutnya sebagai dokumen formal yang berisi: ${ }^{14}$

1. Hasil perjuangan politik bangsa di waktu lampau;

2. Tingkat-tingkat tertinggi perkembangan ketatanegaraan bangsa;

3. Pandangan tokoh-tokoh bangsa yang hendak diwujudkan, baik untuk waktu sekarang, maupun untuk masa yang akan datang; dan

4. Suatu keinginan dengan perkembangan kehidupan ketatanegaraan bangsa hendak dipimpin.

Tentang materi muatan konstitusi, Sri Soemantri mengutip pendapat J.G. Steenbeek menjelaskan tiga materi dasar, yaitu: ${ }^{15}$

13 K.C. Wheare, Modern Constitution, London: Oxford University Press, 1966.

14 Sri Soemantri, Konstitusi Indonesia: Prosedur dan Sistem Perubahannya Sebelum dan Sesudah UUD 1945 Perubahan, Bandung: PT Remaja Rosdakarya, 2016, hlm. 2.

15 Ibid., hlm. 44. 
1. Jaminan terhadap hak asasi manusia dan warga negara;

2. Susunan ketatanegaraan suatu negara yang bersifat fundamental; dan

3. Pembagian dan pembatasan tugas ketatanegaraan yang juga bersifat fundamental.

Salah satu materi penting konstitusi yang menarik perhatian Sri Soemantri berkenaan dengan perubahan, yang kemudian dijadikannya sebagai penelitian disertasi, khususnya ketentuan Pasal 37 UUD 1945. Hal ini didasarkan pada satu pertanyaan penting yang diajukannya yaitu "dapatkah generasi yang hidup sekarang ini mengikat generasi yang akan datang?" Terhadap pertanyaan tersebut SriSoemantri berpendapat: ${ }^{16}$

1. Generasi yang hidup sekarang tidak dapat mengikat generasi yang akan datang.

2. Hukum Konstitusi hanyalah salah satu bagian dari HTN.

3. Ketentuan-ketentuan yang terdapat dalam setiap konstitusi atau UUD selalu dapat diubah.

Tiga hal yang hendak dibuktikannya dalam disertasi yang ditulisnya dari tahun 1976-1978, meliputi:

1. Mengubah UUD 1945 adalah masalah hukum, dalam hal ini Hukum Konstitusi Indonesia.

2. Prosedur serta sistem perubahan UUD 1945 seharusnya mewujudkan dua hal, yaitu menjamin kelangsungan hidup bangsa Indonesia dan memungkinkan adanya perubahan.

3. Persyaratan seperti yang diatur dalam Pasal 37 UUD 1945 belum meliputi prosedur serta sistem perubahan konstitusi yang seharusnya ditempuh.

Berkaitan dengan perubahan, menurut Sri Soemantri terdapat empat permasalahan utama, yaitu: ${ }^{17}$

1. Prosedur dan mekanisme;

2. Sistem perubahan;

3. Bentuk hukum; serta

4. Substansi yang akan diubah.

Khusus terhadap pertanyaan, apakah sifat perubahan UUD merupakan masalah hukum atau masalah politik, Sri Soemantri tegas berpendapat bahwa perubahan merupakan ranah hukum. Meskipun ia mengakui adanya aspek politik dalam perubahan, namun aspek hukum lebih dominan. Secara ringkas disebutnya "wewenang mengubah Undang-Undang Dasar adalah masalah hukum yang mengandung aspek politik". ${ }^{18} \mathrm{Hal}$ ini didasarkan pada argumentasi sebagai berikut.

\footnotetext{
16 Ibid., hlm. 7.

17 Sri Soemantri, Hukum Tata Negara Indonesia: Pemikiran dan Pandangan, Bandung: PT Remaja Rosdakarya, hlm. 22.

18 Sri Soemantri, Konstitusi Indonesia..., Op.cit., hlm. 134.
} 
Pasal 37 UUD memberikan kekuasaan kepada MPR untuk melakukan perubahan, dan kekuasaan tersebut dituangkan dalam wujud tugas serta wewenang. Pengaturan tentang tugas dan wewenang MPR tersebut masuk dalam bidang HTN. Hal ini sejalan dengan pendapat Logemann mengenai obyek penyelidikan HTN, yaitu: ${ }^{19}$

1. Jabatan-jabatan apa yang terdapat dalam susunan ketatanegaraan tertentu;

2. Siapakah yang mengadakan jabatan-jabatan itu;

3. Bagaimanakah cara melengkapinya dengan jabatan;

4. Apakah tugasnya (lingkungan pekerjaan);

5. Apakah wewenangnya;

6. Perhubungan kekuasaan satu sama lain;

7. Dalam batas-batas apakah organisasi negara (dan bagian-bagiannya) menjalankan tugas kewajibannya.

Berkaitan dengan materi muatan apa yang dapat diubah, Sri Soemantri secara spesifik menyatakan:

“... dapat diubah atau tidaknya Pembukaan Undang-Undang Dasar pertama-tama adalah masalah politik. Kecuali ditentukan dalam Undang-Undang Dasar, masalah dapat diubah atau tidaknya Pembukaan tidak dapat diatur dalam peraturan perundang-undangan yang lain, termasuk Ketetapan MPR. Dengan lain perkataan, hal itu harus diatur dalam Undang-Undang Dasar." 20

Selanjutnya dikatakan oleh Sri Soemantri karena perubahan UUD merupakan masalah yang sangat penting, ia berpendapat ketentuan perubahan harus diperberat guna mencegah usaha dari golongan atau anggota yang hendak mengubah UUD 1945. Pasal 37 UUD 1945 sebelum perubahan dipandangnya sebagai ketentuan yang menggolongkan UUD 1945 sebagai konstitusi rigid yakni konstitusi yang sulit diubah karena perubahannya membutuhkan persyaratanpersyaratan khusus. ${ }^{21}$

\section{Politik Hukum}

Sri Soemantri dikenal sebagai salah satu peletak dasar mata kuliah Politik Hukum di berbagai universitas di Indonesia. Di FH Unpad, mata kuliah ini diajarkan pada semua jenjang pendidikan, bahkan menjadi mata kuliah wajib pada program S2 dan S3. Pada saat Prof. Mahfud MD mempertahankan disertasi di Fakultas Hukum UGM, Sri Soemantri bertindak sebagai salah satu penguji.

Meskipun diakuinya bahwa hukum, khususnya undang-undang, terpengaruh

\footnotetext{
19 Ibid., hlm. 131.

20 Ibid., hlm. 150.

21 Sri Soemantri, Persepsi Terhadap Prosedur dan Sistem Perubahan Konstitusi Dalam Batang Tubuh UndangUndang Dasar 1945, Bandung: Alumni, 1986, hlm. 71.
} 
oleh politik, bahkan sebagai produk politik, namun politik hukum bukanlah obyek kajian dari IImu Politik, melainkan IImu Hukum. Hal ini diperolehnya sebagai hasil dari membaca dan menganalisis berbagai pendapat para ahli mengenai politik hukum, terutama Prof. Padmo Wahjono dan Teuku Moh. Radhie, S.H. (Mantan Kepala Badan Pembinaan Hukum Nasional). Menurut Padmo Wahjono, politik hukum adalah "kebijakan dasar yang menentukan arah, bentuk, dan isi hukum yang akan dibentuk". Dari definisi tersebut, Sri Soemantri mengajukan tiga pertanyaan mendasar, yaitu: ${ }^{22}$

1. Apa yang dimaksud dengan kebijakan dasar;

2. Apa yang dimaksud dengan arah hukum, bentuk hukum, dan isi hukum;

3. Apa makna 'akan dibentuk'.

Terhadap frasa 'kebijakan dasar', Sri Soemantri menyatakan bahwa frasa tersebut menunjuk pada kebijakan dasar yang ditemukan dalam konstitusi atau undang-undang dasar. UUD 1945 memuat beberapa politik hukum, misalnya, kebijakan mengenai kekuasaan kehakiman yang terdapat dalam Pasal 24 serta kebijakan dasar lainnya sebagaimana diatur dalam Pasal II Aturan Peralihan, yang disebutnya sebagai hukum transitor. Contoh lain dapat ditemukan dalam Pasal 101 dan 102 Undang-Undang Dasar Sementara 1950 (UUDS 1950).

Pasal 101 berbunyi,

“Perkara perdata, perkara pidana sipil dan perkara pidana militer semata-mata masuk perkara yang diadili oleh pengadilan-pengadilan yang diadakan atau diakui dengan undang-undang atau atas kuasa undang-undang".

Selanjutnya, Pasal 102 menentukan:

"Hukum perdata dan hukum dagang, hukum pidana sipil maupun hukum pidana militer, hukum acara perdata dan hukum acara pidana, susunan dan kekuasaan pengadilan diatur dengan undang-undang dalam kitab-kitab hukum, kecuali jika pengundang-undang menganggap perlu untuk mengatur beberapa hal dalam undangundang tersendiri".

Dengan demikian, Pasal 102 menentukan politik hukum kodifikasi sebagaimana diketahui dari frasa yang berbunyi 'dalam kitab-kitab hukum'.

Arah hukum menurut Sri Soemantri berkenaan dengan kebijakan hukum, dalam arti apakah hendak ke arah unifikasi atau pluralisme hukum, sedangkan bentuk hukum menunjuk pada bentuk-bentuk peraturan perundang-undangan serta tata urutannya sebagaimana terdapat dalam Undang-Undang Nomor 12 Tahun 2011 tentang Pembentukan Peraturan Perundang-undangan yang terdiri dari UUD 1945,

22 Sri Soemantri, Hukum Tata Negara Indonesia...., Op.cit., hlm. 123-127. 
Tap MPR, UU/Perpu, PP, Perpres dan Perda Provinsi serta Perda Kabupaten/Kota. Isi hukum berkaitan dengan substansi atau materi muatan peraturan perundangundangan. Lebih lanjut Sri Soemantri menjelaskan bahwa isi hukum berkaitan pula dengan materi hukum yang akan diatur dalam berbagai cabang hukum dan sesuai dengan sistem hukum maka cabang-cabang hukum tersebut meliputi HTN, Hukum Perdata, Hukum Pidana, dan Hukum Administrasi Negara.

Hal ketiga dari definisi politik hukum Padmo Wahjono berkenaan dengan frasa 'akan dibentuk'. Menurut Sri Soemantri frasa tersebut menunjuk pada hukum yang akan dibentuk atau dibuat atau singkatnya hukum yang akan datang (ius constituendum).

Pendapat ahli kedua yang seringkali dirujuk oleh Sri Soemantri adalah Teuku Moh. Radhie, yang mengartikan politik hukum sebagai "pernyataan kehendak Penguasa Negara mengenai hukum yang berlaku di wilayahnya dan mengenai arah ke mana hukum hendak dikembangkan". ${ }^{23}$ Tidak berbeda dengan pendekatan di atas, Sri Soemantri menganalisis pengertian di atas dengan beberapa pertanyaan, yakni:

1. Apa yang dimaksud sebagai pernyataan kehendak Penguasa Negara;

2. Apa yang dimaksud sebagai hukum yang berlaku di wilayahnya;

3. Apa yang dimaksud mengenai arah ke mana hukum hendak dikembangkan.

Berkenaan dengan pertanyaan mengenai apa yang dimaksud dengan 'Penguasa Negara', Sri Soemantri menjelaskan melalui arti negara sebagai organisasi kekuasaan di mana pusat-pusat kekuasaan negara terwujud dalam fungsi, tugas, dan wewenang lembaga-lembaga negara serta pejabat-pejabat negara. Menariknya, Sri Soemantri menyatakan perubahan UUD 1945 menambah jumlah lembaga negara, yaitu MPR, DPR, DPD, Presiden/Wakil Presiden, BPK, MA, MK, serta KY. ${ }^{24}$ Dari sejumlah lembaga negara tersebut, Sri Soemantri menjelaskan hanya lembaga-lembaga tertentu yang dapat membentuk politik hukum melalui pernyataan kehendaknya, meliputi: MPR; DPR bersama-sama dengan DPD dan Presiden; Presiden sendiri; dan MA. Adapun bentuk-bentuk hukum pernyataan kehendak sejalan dengan wewenang masing-masing lembaga. MPR dalam bentuk UUD dan Ketetapan MPR (sebelum perubahan); DPR, Presiden dan DPD berupa UU; Presiden melalui Perppu, PP dan Perpres. MA membentuk politik hukum melalui putusan-putusannya. ${ }^{25}$ Daniel Lev pernah membuat tulisan dengan judul Mahkamah Agung dan Politik Hukum Waris Adat. ${ }^{26}$

Menjawab pertanyaan kedua berkenaan dengan arti 'hukum yang berlaku di

\footnotetext{
23 Ibid., hlm. 127-130.

${ }^{24}$ Ibid., hlm. 127-128.

25 Ibid., hlm. 129.

26 Ibid.
} 
wilayahnya', Sri Soemantri mengartikan sebagai hukum yang berlaku di wilayah Indonesia (ius constitutum), termasuk pula aturan peralihan mengenai perubahan status suatu daerah yang bertujuan mencegah terjadi kekosongan hukum. Aturan peralihan lainnya yaitu berkenaan dengan adanya peraturan baru yang mengatur materi muatan yang telah ada dalam peraturan sebelumnya. Aturan peralihan semacam ini bertujuan untuk menjamin kepastian hukum. ${ }^{27}$

Terakhir, mengenai arah pengembangan hukum, Sri Soemantri menyatakan bahwa makna dari frasa tersebut menunjuk pada ius constituendum. Artinya politik hukum tentang ke arah mana hukum hendak dibentuk, misalnya politik hukum kodifikasi, politik hukum unifikasi, atau hukum material atau hukum formal apa yang hendak dibuat. ${ }^{28}$

\section{Sistem Pemerintahan, Sistem Kepartaian, dan Kelembagaan Negara}

Sebagaimana ahli lainnya, Sri Soemantri mengartikan sistem pemerintahan berkaitan erat dengan sistem pertanggungjawaban dalam relasi legislatif dan eksekutif. Menurutnya, terdapat tiga sistem pemerintahan, meliputi sistem parlementer; presidensil; dan semi presidensil yang mengandung unsur-unsur sistem parlementer dan presidensil. ${ }^{29}$

Sistem apakah yang dianut oleh Indonesia? Agak berbeda dengan ahli HTN Indonesia lain, Sri Soemantri berpendapat bahwa sebelum perubahan, Indonesia menganut sistem pemerintahan semi presidensial atas dasar beberapa alasan, ${ }^{30}$ antara lain, Presiden memegang kekuasaan pemerintahan menurut UUD dengan masa jabatan lima tahun. Hal ini mencirikan sistem pemerintahan presidensil. Adapun unsur sistem parlementer dijumpai pada pemberhentian Presiden oleh MPR karena MPR lah yang memilih Presiden. ${ }^{31}$ Setelah perubahan, sistem pemerintahan Indonesia menurut Sri Soemantri adalah sistem presidensil. ${ }^{32}$ Selain ketentuan Pasal 4 ayat (1) UUD 1945 yang menyatakan bahwa Presiden memegang kekuasaan pemerintahan, ciri-ciri sistem presidensil secara jelas dapat terlihat dalam perubahan ketiga dimana Presiden tidak lagi dipilih dan bertanggung jawab kepada MPR. Pasal 6A UUD 1945 mengatur "Presiden dan Wakil Presiden dipilih dalam satu pasangan secara langsung oleh rakyat".

Berjalannya sistem pemerintahan ditentukan pula oleh sistem kepartaian apa yang dianut oleh negara yang bersangkutan. Hubungan antara sistem pemerintahan dan sistem kepartaian tersebut juga menjadi kajian Sri Soemantri

\footnotetext{
27 Ibid., hlm. 130.

28 Ibid.

29 Ibid., hlm. 161.

30 Ibid., hlm. 168. Lihat pula Sri Soemantri, Sistim Dua Partai, Bandung: Bina Tjipta, 1968, hlm. 21.

31 Ibid., hlm. 167-168.

32 Ibid., hlm. 170, 181.
} 
yang kemudian menuangkannya dalam buku berjudul 'Sistim Dua Partai' sebagai tanggapan atas usulan Mayjen H.R. Dharsono Pangdam VI Siliwangi saat itu. ${ }^{33}$ Terdapat tiga pertanyaan dasar yang dibahas dalam buku tersebut, yaitu: ${ }^{34}$

1. Apakah yang dimaksud dengan sistem dua partai itu?

2. Dengan cara bagaimanakah sistem dua partai di atas dapat dijalankan atau dilaksanakan?

3. Bagaimanakah pengaruh sistem dua partai itu terhadap kestabilan politik atau pemerintahan pada khususnya serta kehidupan politik di Indonesia pada umumnya?

Menurut Sri Soemantri, apabila Indonesia menganut sistem dua partai maka di dalam MPR akan terdapat dua partai politik yang mempunyai pengaruh besar dalam kehidupan politik dan di antara kedua partai tersebut salah satu akan menguasai suara terbanyak mutlak kursi didalamnya. Presiden akan berasal dari partai politik yang dipercaya oleh partai politik yang menguasai MPR. Hal ini akan berakibat pada kestabilan jalannya pemerintahan sehingga memungkinkan terlaksananya tugas maupun program-program kerja Presiden atau Pemerintah. Selanjutnya dikatakannya, "oleh karena tidak ada perbedaan dalam political thesesnya, maka oposisi sebagai koreksi ini akan ditujukan kepada pelaksanaan program Pemerintah. Oposisi yang demikian ini oleh karenanya akan selalu bersifat oposisi yang loyal". ${ }^{35}$

Mengenai kelembagaan negara, Sri Soemantri mengatakan bahwa seluruh badan-badan yang diatur dalam UUD 1945 dikategorikan sebagai lembaga negara. Sebelum perubahan, lembaga-lembaga tersebut dibagi menjadi dua kategori yakni Lembaga Negara Tertinggi dan Lembaga Negara Tinggi. Dengan menafsirkan frasa "dilakukan sepenuhnya oleh Majelis Permusyawaratan Rakyat" berkenaan dengan kedaulatan rakyat di Indonesia, Sri Soemantri menyatakan sudah semestinya menempatkan MPR sebagai lembaga tertinggi. Lebih lanjut kata 'sepenuhnya' dimaknainya bahwa MPR merupakan satu-satunya lembaga yang melaksanakan kedaulatan rakyat dalam tingkat tertinggi. ${ }^{36}$ Argumentasi utama didasarkan pada arti MPR sebagaimana tertuang dalam Penjelasan Umum UUD 1945 tentang Sistem Pemerintahan Negara yang menyatakan MPR sebagai penjelmaan seluruh rakyat Indonesia ${ }^{37}$ yang tercermin dalam komposisi keanggotaan yang terdiri atas anggota-anggota DPR serta utusan-utusan daerah dan golongan yang berfungsi

\footnotetext{
33 Sri Soemantri, Sistim Dua Partai, Bandung: Bina Tjipta, 1968.

${ }^{34}$ Ibid., hlm. 5.

35 Ibid., hlm. 22.

${ }^{36}$ Sri Soemantri, Hukum Tata Negara Indonesia..., Op.cit., hlm. 73.

37 Ibid. MPR dikatakan sebagai "Vertretungsorgan des Willens des Staatsvolkes" yang berarti "badan yang mewakili kehendak rakyat".
} 
dapat membina kesatuan bangsa dan negara. ${ }^{38}$ Adapun yang dimaksud sebagai Lembaga Negara Tinggi meliputi DPR, Presiden, DPA, BPK dan MA.

Setelah perubahan, sebutan Lembaga Tertinggi dan Tinggi Negara ditiadakan seiring dengan perubahan Pasal 1 ayat (2) UUD 1945. Jika sebelumnya, norma konstitusi menyatakan bahwa kedaulatan rakyat dilaksanakan sepenuhnya oleh MPR, setelah perubahan menjadi kedaulatan berada di tangan rakyat dan dilaksanakan menurut UUD. Selain itu, keseluruhan lembaga negara yang diatur dalam UUD 1945 disebutnya sebagai alat perlengkapan negara. ${ }^{39}$

\section{E. Kontribusi dan Tanggapan}

Dari berbagai paparan di atas, terlihat beragam kontribusi pemikiran Sri Soemantri yang jalin menjalin antara HTN, Hukum Konstitusi, Hukum Lembaga Negara, Ilmu Politik, serta Ilmu Negara. Dengan demikian dapat dikatakan bahwa Sri Soemantri merupakan ahli yang mendalami Ilmu Kenegaraan, baik hukum maupun nonhukum. Dalam pada itu, pandangan-pandangannya banyak dipengaruhi oleh ahliahli HTN Belanda, dibandingkan dengan ahli-ahli HTN dari negara-negara lain, misalnya, Amerika Serikat. Ahli-ahli Belanda yang seringkali dikutipnya, antara lain, Logemann, T. Koopmans, A.M. Donner, Belinfante, Crince Le Roy, Hanc van Maarseven, serta Ger van der Tang. Hal ini tidak mengherankan mengingat ia pernah melakukan sandwich program dalam rangka penelitian dan penulisan disertasi. Beberapa ahli HTN atau Hukum Konstitusi lain yang sering disebutnya, misalnya, K.C. Wheare, C.F. Strong, serta Maurice Duverger.

\section{Konstitusi}

Tidak dapat dibantah, Sri Soemantri merupakan salah satu ahli HTN Indonesia yang 'mengkhususkan' dirinya pada Hukum Konstitusi. Keinginannya agar ketentuan perubahan UUD 1945 diperberat menjadi kenyataan seiring dengan dimasukkannya beberapa syarat baru perubahan sebagaimana diatur dalam Pasal 37 UUD 1945, meliputi:

1. Usul perubahan harus diajukan sekurang-kurangnya oleh $1 / 3$ dari jumlah anggota MPR.

2. Setiap usul perubahan pasal-pasal diajukan secara tertulis disertai alasan perubahan.

3. Perubahan tidak dapat dilakukan untuk bentuk Negara Kesatuan Republik Indonesia.

Sri Soemantri berkeyakinan berbagai syarat baru tersebut penting sebagai salah

\footnotetext{
38 Sri Soemantri, Tentang Lembaga-Lembaga Negara Menurut UUD 1945, Bandung: Alumni, 1986, hlm. 49-50.

${ }^{39}$ Sri Soemantri, Hukum Tata Negara Indonesia...., Op.cit., hlm. 127-128.
} 
satu cara menjaga wibawa konstitusi. Penambahan syarat ini sekaligus menunjukkan bahwa perubahan hanya dapat dilakukan secara sangat berhati-hati dalam situasi yang benar-benar menghendaki perubahan. Dalam istilah James Madison disebut sebagai 'great and extraordinary occasion' ${ }^{40}$ Pengalaman Amerika Serikat menunjukkan hal menarik saat sekelompok orang yang tergabung dalam kelompok Citizens for the Constitution mempublikasikan pandangan mereka mengenai perubahan konstitusi. ${ }^{41}$ Dalam Guidelines for Constitutional Amendment, kelompok ini mengajukan beberapa syarat atau kriteria yang menunjukkan karakter 'pengekangan diri' atau self restraint dalam perubahan konstitusi. Syarat-syarat tersebut meliputi: ${ }^{42}$

1. Does the proposed amendment address matters that are of more than immediate concern and that are likely to be recognized as of abiding importance bysubsequent generations?

2. Does the proposed amendment make our system more politically responsive or protect individual rights?

3. Are there significant practical or legal obstacles to the achievement of the objectives of the proposed amendment by other means?

4. Is the proposed amendment consistent with related constitutional doctrine that the amendment leaves intact?

5. Does the proposed amendment embody enforceable and not purely aspirational standards?

6. Have proponents of the proposed amendment attempted to think through and articulate the consequences of their proposal, including the ways in which the amendment would interact with other constitutional provisions and principles?

7. Has there been full and fair debate on the merits of the proposed amendment?

8. Has Congress provided for a non-extendable deadline for ratification by the states so as to ensure that there is contemporaneous consensus by Congress and the states that the proposed amendment is desirable?

Berkenaan dengan ketentuan UUD 1945 mengenai perubahan, terdapat paling tidak dua isu menarik dari ketentuan baru tersebut. Pertama, mengenai usul perubahan. Dalam pandangan Penulis, pengusul mengajukan materi perubahan sekaligus rancangan norma perubahan. Dalam kaitan ini, apakah pengusulan tersebut bersifat tertutup, dalam arti baik materi maupun rancangan pasal tidak dapat diubah, selain oleh pengusul. Ataukah, pengusulan ini bersifat terbuka, yang memungkinkan para anggota MPR yang bukan pengusul dapat melakukan

\footnotetext{
40 Alexander Hamilton, James Madison, John Jay, The Federalist Papers, New York: Mentor Book, 1961, hlm. 314.

41 Bagir Manan dan Susi Dwi Harijanti, Memahami Konstitusi: Makna dan Aktualisasi, Jakarta: PT RajaGrafindo Persada, 2014, hlm. 195-196.

42 Ibid., hlm. 196.
} 
perubahan terhadap materi dan rancangan pasal? Penulis berpendapat, sepanjang berkenaan dengan materi, perubahan tidak dapat dilakukan oleh mereka yang bukan pengusul, untuk menghindarkan perubahan bersifat masif yang tidak didasarkan pada argumentasi atau asas kebutuhan yang bersifat mendasar atau fundamental. Kedua, tentang larangan perubahan bentuk negara. Apakah dengan larangan ini berarti bahwa generasi sekarang dapat mengikat generasi yang akan datang, yang berarti secara diametral berbeda dengan pendapat yang dibangun oleh Sri Soemantri dalam disertasinya yang menyatakan bahwa generasi yang sekarang tidak dapat mengikat generasi yang akan datang.

Dalam disertasi, Sri Soemantri menegaskan "sulit untuk mengatakan, bahwa tanpa adanya peraturan tentang pembatasan berarti semua bagian dari konstitusi dapat diubah". ${ }^{43}$ Dengan kata lain, pembatasan memang menjadi keniscayaan, terutama setelah melihat pengalaman Perancis di mana Pasal 89 ayat (6) Konstitusi 1958 secara tegas menyatakan bentuk pemerintahan republik tidak dapat dijadikan sebagai objek perubahan. Sebagaimana dijelaskan di atas, menurut Sri Soemantri pada akhirnya apakah pembatasan itu dipatuhi akan sangat tergantung pada faktor politik. ${ }^{44}$

Dalam perkembangan teori konstitusi, larangan perubahan terhadap materi atau pasal tertentu secara populer dikenal sebagai unamendable provision atau non-amendable provision. Atau lazim pula disebut sebagai unconstitutional constitutional amendment. ${ }^{45}$ Konsep atau ide mengenai unconstitutional constitutional amendment merupakan ide yang memunculkan teka teki. Apakah mungkin suatu perubahan konstitusi dipandang bertentangan dengan konstitusi itu sendiri. Jika dianggap bertentangan, alasan apa yang digunakan untuk menyatakan pertentangan tersebut. Pada Juni 2008, Mahkamah Konstitusi Turki membatalkan perubahan konstitusi yang dilakukan oleh Parlemen berkenaan dengan prinsip persamaan dan hak atas pendidikan. ${ }^{46}$ Parlemen Turki hendak menghapuskan larangan penggunaan penutup kepala di universitas-universitas. Mahkamah Konstitusi menyatakan penghapusan larangan tersebut bertentangan dengan prinsip sekularisme. Melihat pada contoh Turki, apakah dapat dikatakan bahwa terdapat prinsip-prinsip tertentu dalam konstitusi yang bersifat supreme sehingga djadikan sebagai 'batu uji' untuk menilai konstitusionalitas perubahan? Bahkah, lebih lanjut dapat menyeret pada situasi dimana terjadi konflik atau pertentangan

\footnotetext{
${ }^{43}$ Sri Soemantri, Persepsi Terhadap Prosedur dan Sistem Perubahan Konstitusi..., Op.cit., hlm. 151.

44 Ibid.

45 Yaniv Roznai, "Unconstitutional Constitutional Amendment: A Study of the Nature and Limits of Constitutional Amendment Powers", Disertasi, The London School of Economics 2014, http://etheses.Ise.ac.uk/915/1/Roznai_Unconstitutional-constitutional-amendment.pdf, diunduh 5 Agustus 2016.

46 Ibid., hlm. 13.

47 Ibid., hlm. 15.
} 
antara aspek substantif dan aspek prosedural dari perubahan konstitusi. ${ }^{4}$

\section{Politik Hukum}

Sri Soemantri sebagaimana telah disebutkan bahwa ia adalah salah satu ahli yang mengembangkan kajian politik hukum di Indonesia. Menariknya, ia berusaha menemukan argumentasi letak Politik Hukum dalam cabang ilmu, dalam arti apakah politik hukum termasuk kajian IImu Politik atau Ilmu Hukum. Secara tegas, dikatakannya bahwa Politik Hukum merupakan bagian dari Ilmu Hukum dengan cara menafsirkan berbagai pengertian Politik Hukum menurut beberapa ahli, termasuk Padmo Wahjono dan Teuku Moh. Radhie.

Jika merujuk pada pendapat Sri Soemantri mengenai materi pokok dalam Politik Hukum, terdapat tiga bahasan utama, yaitu: peraturan, substansi, dan jangkauan. Peraturan menunjuk pada jenis peraturan yang memuat poltik hukum, misalnya UUD, UU, atau peraturan lain, termasuk pula di dalamnya lembaga atau badan pembentuk peraturan tersebut. Substansi politik hukum dapat berkaitan dengan hal-hal seperti pilihan antara kodifikasi atau unifikasi, sedangkan jangkauan menunjuk pada ius constitutum dan/atau ius constituendum.

Pendapat mengenai ruang lingkup Politik Hukum, antara lain, juga dikemukakan oleh Bagir Manan. Dalam salah satu makalahnya, Bagir membagi ruang lingkup ini menjadi dua, yakni politik pembentukan hukum yang berkenaan dengan kebijakan penciptaan, pengembangan dan pembaharuan hukum, yang meliputi kebijakan pembentukan peraturan perundang-undangan, yurisprudensi, serta kebijakan hukum tidak tertulis lainnya. Lingkup kedua yaitu politik penegakan hukum yang meliputi kebijakan di bidang peradilan dan pelayanan. Kedua ruang lingkup tersebut dapat dibedakan namun tidak dapat dipisahkan atas dasar alasan-alasan sebagai berikut:

(1) Keberhasilan pembentukan suatu peraturan perundang-undangan tergantung pada penerapannya. Jika penegakan tidak berjalan dengan baik, maka tujuan pembentukan tidak tercapai.

(2) Putusan dalam penegakan menjadi instrumen kontrol bagi ketepatan atau kekurangan peraturan perundang-undangan. Putusan dapat berfungsi sebagai masukan bagi penyempurnaan atau pembaharuan suatu peraturan perundangundangan.

(3) Penegakan merupakan dinamisator bagi peraturan perundang-undangan. Melalui putusan, peraturan perundang-undangan menjadi hiudp dan diterapkan sesuai dengan kebutuhan dan perkembangan masyarakat. Peraturan yang kurang baik dapat mencapai tujuan pembentukan di tangan penegak hukum yang baik.

\footnotetext{
48 Bagir Manan, “Hubungan Ketatanegaraan Mahkamah (dan Mahkamah Konstitusi) Dengan Komisi Yudisial: Suatu Pertanyaan", Makalah, 2006, hlm. 1.
} 
Dalam perkembangannya, sekitar akhir 1990-an, Bagir Manan menyempurnakan pendapatnya mengenai ruang lingkup dengan menggunakan elemen sistem hukum yang diperkenalkan oleh Lawrence Friedman, yang meliputi struktur hukum, substansi hukum, serta budaya hukum. Pada pertengahan 2000an, Bagir memasukkan pendidikan hukum sebagai elemen politik hukum. Pentingnya memasukkan pendidikan tinggi hukum ini didasarkan pada pemikiran bahwa pendidikan tinggi hukum menghasilkan para lulusan yang mengisi berbagai jabatan di masyarakat, baik pada level pemerintahan maupun swasta.

\section{Lembaga-lembaga Negara}

Tentang lembaga-lembaga negara, pandangan Sri Soemantri mengenai hal ini berbeda dengan pendapat Bagir Manan. Sebagaimana disebutkan, Sri Soemantri menggolongkan semua lembaga negara yang diatur dalam UUD 1945 sebagai alat perlengkapan negara. Sebaliknya, Bagir Manan menyatakan bahwa tidak semua lembaga yang eksistensinya diatur dalam UUD 1945 secara otomatis dikualifikasikan sebagai alat perlengkapan negara. Suatu kedudukan, fungsi, dan hubungan ketatanegaraan tidak ditentukan karena suatu badan atau lembaga diatur dalam UUD. ${ }^{48}$ Baginya kualifikasi sebagai alat kelengkapan negara (staats organen) sangat tergantung pada fungsi yang dimilikinya. Ringkasnya, alat kelengkapan negara merupakan badan-badan negara yang bertindak untuk dan atas nama negara. Selengkapnya, Bagir Manan menyatakan:

"Untuk mengetahui, apakah suatu lembaga negara sebagai yang bertindak untuk dan atas nama negara atau bukan, ditentukan oleh aturan substantif mengenai tugas dan wewenang lembaga negara yang bersangkutan. Dengan pengetahuan tersebut, sekaligus diketahui pula, apakah suatu lembaga negara adalah badan ketatanegaraan atau bukan badan ketatanegaraan." 49

Perubahan UUD 1945 mengakibatkan terjadinya lima perubahan berkenaan dengan kelembagaan negara. Perubahan tersebut meliputi: perubahan pengertian, perubahan kedudukan, perubahan tugas dan wewenang, perubahan jenis-jenis lembaga negara, serta perubahan hubungan antara lembaga negara..$^{50}$ Perubahan pengertian, antara lain, meliputi perubahan sifat hukum lembaga-lembaga yang pada dasarnya menunjuk pada fungsi lembagalembaga tersebut. Secara umum, Bagir Manan membagi lembaga-lembaga negara ke dalam: ${ }^{51}$

1. Lembaga negara ketatanegaraan;

2. Lembaga negara administratif;

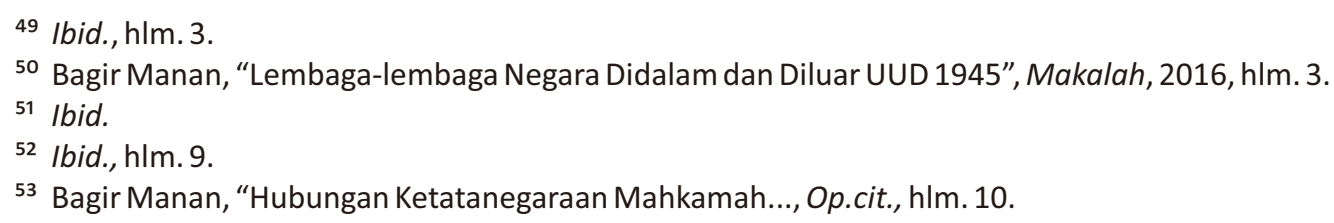


3. Lembaga negara auxiliary; dan

4. Lembaga negara ad hoc.

Perubahan UUD 1945 membawa perubahan kedudukan. MPR menjadi satusatunya lembaga yang mengalami perubahan ini, semula sebagai lembaga tertinggi dan kemudian berubah menjadi lembaga negara yang sejajar dengan lembagalembaga lain yang bersifat ketatanegaraan, yakni DPR, DPD, Presiden, BPK, MA dan MK. Perubahan kedudukan termasuk pula penghapusan lembaga negara, misalnya DPA.

Dari perspektif jenis-jenis lembaga-lembaga, saat ini dikenal berbagai macam lembaga, baik yang diatur di dalam maupun di luar UUD 1945. Menanggapi hal ini, Bagir berpendapat:

"Aneka ragam lembaga dan badan yang diatur di dalam dan di luar UUD, selain karena kerancuan pengertian lembaga negara, juga terjadi karena penyusun perubahan UUD tidak mempunyai satu konsep yang jelas mengenai materi muatan UUD. Penempatan Komisi Yudisial dalam sistematik kekuasaan kehakiman, menimbulkan persepsi, Komisi ini menjalankan fungsi sebagai bagian dari pelaksanaan kekuasaan kehakiman (judicial administration), karena itu berwenang mencampuri (mengawasi) proses yudisial atau yang menurut ajaran atau tradisi merupakan bagian dari fungsi yudisial (judicial function)." 52

Perubahan lain yang penting dicermati adalah perubahan sifat hukum yang akan berakibat antara lain pada perubahan hubungan. Suatu lembaga yang tidak bersifat ketatanegaraan tidak dapat melakukan hubungan yang bersifat ketatanegaraan. ${ }^{53}$ Misalnya, dalam pandangan Bagir, KY bukanlah lembaga yang bersifat ketatanegaraan, oleh sebab itu ia tidak dapat melakukan hubungan ketatanegaraan dengan lembaga lain, misalnya dengan MA dan MK. ${ }^{54}$ Selengkapnya dikatakannya:

"Dengan demikian, hubungan antara Mahkamah Agung dan Mahkamah Konstitusi di satu pihak dengan Komisi Yudisial di lain pihak bukanlah termasuk hubungan ketatanegaraan sehingga tidak bersifat staatsrechtelijk, melainkan sebagai hubungan atributif yang bersifat menunjang dan bersifat administratif belaka."55

\section{F. Epilog}

Akhirnya, keterlibatan Sri Soemantri di Komisi Konstitusi harus dipandang sebagai bagian 'penuntasan sejarah' yang dijalaninya karena pada tahun 1959 sempat

\footnotetext{
54 Ibid.

55 Ibid., hlm. 11.
} 
terhenti akibat Konstituante dibubarkan. Bagi Sri Soemantri berakhirnya tugastugas di Komisi Konstitusi tidak berarti menghentikan pengabdiannya 'mengawal' konstitusi yang menjadi milik rakyat sebagaimana janjinya saat menerima jabatan Guru Besar HTN tahun 1987 seperti dikutip di awal tulisan ini. Tidak banyak ilmuwan HTN yang berkesempatan menjelajahi berbagai bidang kehidupan di kampus dan di luar kampus dan mampu merealisasikan pemikirannya dalam penyelenggaraan negara. Sri Soemantri adalah salah satunya. Keberanian bersikap sebagai ciri ilmuwan dipadu dengan pemahaman utuh mengenai politik, baik teori maupun praktik, menyadarkannya bahwa masalah konstitusi tidak semata-mata bernuansa hukum, melainkan tidak terlepas dari pergulatan kepentingan politik. Hal terpenting adalah membentuk konstitusi rakyat sebagai landasan kokoh bagi penyelenggaraan negara berdasarkan konstitusi guna mewujudkan tujuan bernegara: masyarakat adil dan makmur. Baginya "for a fighting nation, there is no journey end", sebuah ungkapan Mahatma Gandhi yang menginspirasi dan mengukuhkan perjalanannya untuk tetap mengabdi pada jalan ilmu yang diyakininya: Ilmu HTN, yang mengantarnya menerima Muh. Yamin Award dari Pusat Studi Konstitusi Universitas Andalas untuk kategori Lifetime Achievement tahun 2014. 